\title{
MANAJEMEN PEMBIAYAAN BANK SYARIAH: SEBUAH PERKENALAN
}

\author{
Achmad Lubabul Chadziq \\ Institut Keislaman Abdullah Faqih (INKAFA) \\ e-mail: lubab1976@gmail.com
}

\begin{abstract}
The two main functions of banking are fund raising and channeling of funds. Distribution of funds in conventional banks with those contained in Islamic banks has an essential difference, both in terms of names, contracts, and transactions. In the conventional banking, channeling of this fund is known as credit while in sharia banking called as defrayal. Unlike the definition of credit that requires the debtor to repay the loan by giving interest to the bank, the defrayal based on sharia principles, the loan repayment with profit sharing is based on the agreement between the bank and the debtor. For example, defrayal with the principle of sale and purchase which is intended to buy goods, while those who use the principle of lease is intended to obtain services. The profitsharing principle is used for cooperative efforts aimed at obtaining goods and services at once. Financing is a very important activity because with the financing, it will be obtained the main source of income and become a supporting case of the bank business continuity. Conversely, the management of bank which is not good will cause problems and cessation of business bank. Therefore, it is necessary to have a good sharia-financing management so that the distribution or financing to the customer can be effective and efficient in accordance with the objectives of the company and Islamic sharia it self. In this paper, author tries to explain how the concept of sharia financing management it self so that it is expected, both writer, colleague, student, and the public can better understand the management of Islamic finance.
\end{abstract}

Keywords: financing management, sharia bank

\section{Pendahuluan}

Dua fungsi utama perbankan adalah penggalangan dana dan penyaluran dana. Distribusi dana di bank konvensional dengan yang ada di bank syariah memiliki perbedaan penting, baik dari segi nama, kontrak, dan transaksi. Dalam perbankan konvensional, penyaluran dana ini dikenal sebagai kredit sedangkan dalam perbankan syariah disebut sebagai pembiayaan. Berbeda dengan definisi kredit yang mengharuskan debitur untuk membayar kembali pinjaman dengan memberikan bunga kepada bank, pembiayaan berdasarkan prinsip syariah, pembayaran pinjaman dengan pembagian keuntungan didasarkan pada perjanjian antara bank dan debitur. Misalnya, pembiayaan dengan prinsip jual beli yang dimaksudkan untuk membeli barang, sedangkan mereka yang menggunakan prinsip sewa dimaksudkan untuk mendapatkan layanan. Prinsip bagi hasil digunakan untuk upaya koperasi yang bertujuan mendapatkan barang dan jasa sekaligus. Pembiayaan adalah kegiatan yang sangat penting karena dengan pembiayaan, maka akan diperoleh sumber pendapatan utama dan menjadi kasus pendukung kelangsungan bisnis bank. Sebaliknya, pengelolaan bank yang tidak baik akan menimbulkan masalah dan penghentian bisnis bank. Oleh karena itu, perlu 
memiliki manajemen pembiayaan syariah yang baik sehingga distribusi atau pembiayaan kepada pelanggan dapat efektif dan efisien sesuai dengan tujuan.

\section{Pengertian Manajemen Pembiayaan Bank Syariah}

Secara etimologi manajemen berasal dari Bahasa Latin, yaitu dari kata manus yang berarti tangan dan agere yang berarti melakukan. Kedua kata ini digabungkan menjadi kata kerja managere yang artinya menangani. Managere diterjemahkan ke dalam bahasa Inggris dalam bentuk kata kerja to manage dengan kata benda management. Manager untuk orang yang melakukan kegiatan manajemen. Diterjemahkan pula ke dalam bahasa Perancis menagement yang memiliki arti seni melaksanakan dan mengatur. Management kemudian diterjemahkan ke dalam bahasa Indonesia menjadi manajemen atau pengolahan. ${ }^{1}$

Pembiayaan diartikan sebagai suatu kegiatan pemberian fasilitas keuangan (finansial) yang diberikan satu pihak kepada pihak lain untuk mendukung kelancaran usaha maupun untuk investasi yang telah direncanakan. Pembiayaan merupakan salah satu tugas pokok bank, yaitu pemberian fasilitas penyediaan dana untuk memenuhi kebutuhan pihak-pihak yang merupakan deficit unit.

Menurut penulis, pembiayaan adalah suatu produk yang diberikan atau ditawarkan oleh bank kepada nasabah atau masyarakat yang membutuhkan guna menunjang kegiatan perekonomian atau kebutuhan mereka.

Berdasarkan UU Nomor 21 tahun 2008 tentang Perbankan Syariah, bank syariah didefenisikan sebagai bank yang menjalankan kegiatan usahanya berdasarkan prinsip-prinsip syariah.

Jadi, manajemen pembiayaan bank syariah adalah sebuah proses perencanaan, pengorganisasian, pengkoordinasian, dan pengontrolan sumber daya yang dilakukan oleh bank yang menjalankan kegiatan usahanya berdasarkan prinsip-prinsip syariah dalam hal pemberian fasilitas keuangan/finasial kepada pihak lain untuk mendukung kelancaran usaha maupun untuk investasi yang telah direncanakan.

Di samping itu, dalam pelaksanaan pembiayaan, bank syariah memenuhi aspek shar'i dan aspek ekonomi. Yang dimaksud dengan aspek shar' $i$ adalah setiap realisasi pembiayaan kepada nasabah, bank syariah harus tetap berpedoman kepada syariat Islam (antara lain tidak mengandung unsur maysi $\gg$, ghara», dan riba serta bidang usahanya harus halal. Adupun yang dimaksud dengan aspek ekonomi adalah mempertimbangkan perolehan keuntungan baik bagi bank syariah maupun bagi nasabah.

\section{Tujuan dan Fungsi Pembiayaan}

Pembiayaan merupakan sumber pendapatan bagi bank syariah. Tujuan pembiayaan yang dilaksanakan perbankan syariah terkait dengan stakeholder adalah: ${ }^{2}$

1. Pemilik. Dari sumber pendapatan di atas, para pemilik mengharapkan akan memperoleh penghasilan atas dana yang ditanamkan pada bank tersebut.

2. Pegawai. Para pegawai mengharapkan dapat memperoleh kesejahteraan dari bank yang dikelolanya.

\footnotetext{
${ }^{1}$ Hetty Ismaniar, Manajemen Unit Kerja (Yogyakarta: Deepublish, 2015), 36.

${ }^{2}$ Muhammad Syafi'i Antonio, Bank Syariah dari Teori ke Praktik (Jakarta: Gema Insani, 2001), 168.
} 
3. Masyarakat.

a. Pemilik dana; masyarakat sebagai pemilik dana mengharapkan dari dana yang diinvestasikan akan diperoleh bagi hasil.

b. Debitur yang bersangkutan; dengan penyediaan dana baginya mereka merasa terbantu guna menjalankan usahanya (sektor produktif) atau terbantu untuk pengadaan barang yang diinginkannya (pembiayaan konsumtif).

c. Masyarakat (umumnya konsumen); dengan pembiayaan mereka dapat memperoleh barang-barang yang dibutuhkan.

4. Pemerintah. Pemerintah terbantu dalam pembiayaan pembangunan negara, di samping itu akan diperoleh pajak.

5. Bank. Bagi bank yang bersangkutan, hasil dari penyaluran pembiayaan diharapkan bank dapat meneruskan dan mengembangkan usahanya agar tetap survival dan meluaskan jaringan usahanya, sehingga semakin banyak masyarakat yang dapat dilayaninya.

Ada bebarapa fungsi pembiayaan yang diberikan oleh bank syariah kepada masyarakat penerima di antaranya:

1. Meningkatkan daya guna uang

Para penabung menyimpan uangnya di bank dalam bentuk giro, tabungan dan deposito. Uang tersebut dalam prosentase tertentu ditingkatkan kegunaannya oleh bank guna suatu usaha peningkatan produktifitas.

2. Meningkatkan daya guna barang

Produsen dengan bantuan pembiayaan bank dapat memproduksi bahan mentah menjadi bahan jadi sehingga utility dari bahan tersebut meningkat.

3. Meningkatkan peredaran uang

Melalui pembiayaan, peredaran uang kartal maupun giral akan lebih berkembang oleh karena pembiayaan menciptakan suatu kegairahan berusaha sehingga penggunaan uang akan bertambah baik kualitatif apalagi secara kuantitatif.

4. Menimbulkan kegairahan berusaha

Bantuan pembiayaan yang diterima pengusaha dari bank inilah kemudian yang digunakan untuk memperbesar volume usaha dan produktifitas.

5. Stabilitas ekonomi

Dalam ekonomi yang kurang sehat, langkah-langkah stabilitasi pada dasarnya diarahkan pada usaha-usaha untuk antara lain:

a. Pengendalian inflasi.

b. Peningkatan ekspor.

c. Rehabilitasi prasarana.

d. Pemenuhan kebutuhan-kebutuhan pokok rakyat.

e. Sebagai jembatan untuk meningkatkan pendapatan nasional. Para usahawan yang memperoleh pembiayaan tentu saja berusaha untuk meningkatkan usahanya. Peningkatan usaha berarti peningkatan profit/pendapatan.

f. Sebagai alat hubungan ekonomi internasional. Bank sebagai lembaga pembiayaan tidak saja bergerak di dalam negeri tapi juga di luar negeri. Negara-negara kaya atau yang kuat ekonominya, demi persahabatan antar negara banyak memberikan bantuan kepada negara-negara yang sedang berkembang atau yang sedang membangun. 
Bantuan tersebut tercermin dalam bentuk bantuan kredit dengan syarat-syarat tertentu.

\section{Komponen Manajemen Pembiayaan Bank Syariah}

Manajemen pembiayaan pada bank syariah terdiri atas beberapa komponen, yaitu perencanaan pembiayaan; organisasi pembiayaan; dan monitoring pembiayaan. ${ }^{3}$

1. Perencanaan Pembiayaan terdiri atas:

a. Penetapan target pembiayaan, yang meliputi penetapan presentase dari jual beli, bagi hasil dan sewa/sewa beli.

b. Segmen pasar pembiayaan, yang meliputi individu dan korporasi.

c. Strategi pembiayaan dengan menentukan mitra kerjasama, cross selling, promosi dan product development.

2. Organisasi Pembiayaan, terdiri atas:

a. Komite Kebijakan Pembiayaan.

b. Komite Pembiayaan.

c. ALCO (Asset Liability Comittee).

d. Marketing pembiayaan.

e. Support pembiayaan.

f. Operasional pembiayaan.

g. Pengawasan.

3. Proses Pembiayaan

Pada proses ini, tugas komite kebijakan pembiayaan menetapkan batas wewenang persetujuan pembiayaan, menetapkan proses persetujuan pembiayaan, menetapkan format akad pembiayaan, dan menetapkan persetujuan pencairan dana pembiayaan. Adapun tugas komite pembiayaan memeriksa kelayakan pengajuan pembiayaan, memberikan persetujuan pembiayaan sesuai limit. Kemudian tugas tim ALCO adalah menentukan pricing produk pembiayaan. Selanjutnya tugas marketing pembiayaan adalah mengelola penjualan sales intuitivist, mengelola produk cross selling, mengelola account (costumer relationship), melakukan analisis pembiayaan (financing manager). Support pembiayaan bertugas melakukan analisis yuridis/legalitas, melakukan taksasi pembiayaan, melakukan BI checking, melakukan administrasi pembiayaan. Operasional pembiayaan melakukan pencairan bertugas melakukan pencairan pembiayaan, membuat laporan pembiayaan.

4. Monitoring Pembiayaan

Pada tahap ini dilakukan monitoring pencapaian target pembiayaan, monitoring proses pembiayaan pada akad-akad jual beli, bagi hasil, sewa dan sewa beli; prosedur/ketentuan (data-data nasabah); kelancaran pembayaran nasabah, dan lain-lain; mengevaluasi proses pembiayaan.

\section{Jenis-Jenis Pembiayaan Bank Syariah ${ }^{4}$}

1. Pembiyaan Modal Kerja Syariah

\footnotetext{
${ }^{3}$ Ahmad Ifham Sholihin, Buku Pintar Ekonomi Syari'ah (Jakarta: Gramedia Pustaka Utama, 2010), 596.

${ }^{4}$ Muhammad, Manajemen Pembiayaan Bank Syariah (Yogyakarta: UPP AMP YKPN, t.t.), 16.
} 
Secara umum, yang dimaksud dengan pembiayaan modal kerja syariah adalah pembiayaan jangka pendek yang diberikan kepada perusahaan untuk membiayai kebutuhan modal kerja usahanya berdasarkan prinsip-prinsip syariah.

Berdasarkan akad yang digunakan dalam produk pembiayaan syariah, jenis Pembiayaan Modal Kerja (PMK) dapat dibagi menjadi lima macam, yakni:

\section{a. PMK Mudq}

Pembiayaan mudłrabah adalah perjanjian antara peranan dana dan pengelola dana untuk melakukan kegiatan usaha tertentu, dengan pembiayaan keuntungan antara kedua belah pihak berdasarkan nisbah yang telah disepakati sebelumnya.

b. PMK Istishas

Istisła $a>$ adalah perjanjian jual beli dalam bentuk pemesanan pembuatan barang dengan kriteria dan persyaratan tertentu yang disepakati antara pemesan dan penjual.

c. PMK Salam

Salam adalah perjanjian jual beli barang dengan cara pemesanan dengan syarat-syarat tertentu dan pembayaran harga terlebih dahulu.

\section{d. PMK Muraßahłh}

Muraßahłh adalah perjanjian jual beli antara bank dan nasabah di mana bank syariah membeli barang yang diperlukan oleh nasabah dan kemudian menjualnya kepada nasabah yang bersangkutan sebesar harga perolehan ditambah dengan margin/keuntungan yang disepakati antara bank syariah dan nasabah.

\section{e. PMK Ijaฉah}

Ijaæah adalah perjanjian sewa menyewa suatu barang dalam waktu tertentu melalui pembayaran sewa.

2. Pembiayaan Investasi Syariah

Pembiayaan investasi adalah untuk memenuhi kebutuhan barang-barang modal (capital goods) beserta fasilitas-fasilitas yang erat kaitannya dengan itu. Yang dimaksud dengan investasi adalah penanaman dana dengan maksud untuk memperoleh imbalan/manfaat/keuntungan di kemudian hari, mencakup hal-hal berikut, antara lain: ${ }^{5}$

a. Imbalan yang diharapkan dari investasi adalah berupa kentungan dalam bentuk uang.

b. Bahan usaha umumnya bertujuan untuk memperoleh keuntungan berupa uang, sedangkan badan sosial dan badan-badan pemerintah lainnya lebih bertujuan memberikan manfaat sosial dibandingkan dengan keuntungan.

c. Badan-badan usaha yang mendapat pembiyaan investasi dari bank harus mampu memperoleh keuntungan finansial agar dapat hidup dan berkembang serta memenuhi kewajiban kepada bank.

Pembiayaan investasi diberikan kepada nasabah untuk keperluan penambahan modal guna mengadakan rehabilitasi, perluasan usaha ataupun pendirian proyek baru. Ciri-ciri pembiayaan investasi adalah:

a. Untuk pengadaan barang-barang modal.

b. Mempunyai perencanaan yang matang dan terarah.

c. Berjangka waktu menengah dan panjang.

\footnotetext{
${ }^{5}$ Muhammad, Manajemen Dana Bank Syariah (Yogyakarta: Ekonisia, 2004), 183-186.
} 
3. Pembiayaan Konsumtif Syariah

Pembiayaan konsumtif diperlukan oleh pengguna dana untuk memenuhi kebutuhan konsumsi dan akan habis dipakai untuk memenuhi kebutuhan tersebut. Kebutuhan konsumsi dapat dibedakan atas kebutuhan primer (pokok atau dasar) dan kebutuhan sekunder. Kebutuhan primer adalah kebutuhan pokok, baik berupa barang, seperti makanan, minuman, pakaian, dan tempat tinggal, maupun berupa jasa, seperti pendidikan dasar dan pengobatan. Sedangkan kebutuhan sekunder adalah kebutuhan tambahan, yang secara kuantitatif maupun kualitatif lebih tingi atau lebih mewah dari kebutuhan primer, baik berupa barang, seperti makanan dan minuman, pakaian/perhiasan, bangunan rumah, kendaraan, dan sebagainya, maupun berupa jasa seperti pendidikan, pelayanan kesehatan, pariwisata, hiburan, dan sebagainya.

Menurut jenis akadnya dalam produk pembiayaan syariah, pembiayaan konsumtif dapat dibagi menjadi lima bagian, yaitu: ${ }^{6}$

a. Pembiayaan konsumen akad muraßahłh .

b. Pembiayaan konsumen akad IMBT.

c. Pembiayaan konsumen akad ija $a$ ah.

d. Pembiayaan konsumen akad istisła 3 .

e. Pembiayaan konsumen akad qard dan ija $a$ ah

Dalam menetapkan akad pembiyaan konsumtif, langkah-langkah yang perlu dilakukan bank adalah sebagai berikut:

a. Apabila kegunaan pembiayaan yang dibutuhkan nasabah adalah untuk kebutuhan konsumtif semata, harus dilihat dari sisi apakah pembiyaan tersebut berbentuk pembiayaan barang atau jasa.

b. Jika untuk pembelian barang, faktor selanjutnya yang harus dilihat adalah apakah barang tersebut berebentuk ready stock atau good in process. Jika ready stock pembiayaan yang diberikan adalah pembiayaan murabahłh. Namun, jika berbentuk good in process, yang harus dilihat berikutnya adalah dari sisi apakah proses barang tersebut memerlukan waktu di bawah enam bulan atau lebih. Jika di bawah enam bulan, pembiayaan yang diberikan adalah pembiayaan salam. Jika proses barang tersebut memerlukan waktu lebih dari enam bulan, pembiayaan yang diberikan adalah istishas?

c. Jika pembiayaan tersebut dimaksudkan untuk memenuhi kebutuhan nasabah di bidang jasa, pembiyaan yang diberikan adalah ijazah.

4. Pembiayaan Sindikasi

Pembiayaan sindikasi adalah pembiayaan yang diberikan oleh lebih dari satu lembaga keuangan bank untuk satu obejek pembiayaan tertentu. Pada umumnya pembiayaan ini diberikan kepada nasabah korporasi yang memiliki nilai transaksi yang sangat besar. Pembiayaan sindikasi memiliki tiga bentuk yakni: ${ }^{7}$

\footnotetext{
${ }^{6}$ Adiwarman A. Karim, Bank Islam (Jakarta: PT. Raja Grafindo Persada, 2010), 234-235.

${ }^{7}$ Muhammad, Manajemen Pembiayaan, 188.
} 
a. Lead syndication, yakni sekelompok bank yang secara bersama-sama membiaya suatu proyek dan dipimpin oleh satu bank yang bertindak sebagai leader. Modal yang diberikan masing-masing bank dilebur menjadi satu kesatuan, sehingga keuntungan dan kerugian menjadi hak bersama, sesuai dengan proporsi modal masing-masing.

b. Club deal, yakni sekelompok bank yang secara bersama-sama membiayai suatu proyek, tetapi di antara bank yang satu dan bank yang lain tidak mempunyai hubungan kerjasama bisnis dalam arti penyatuan modal. Masing-masing bank membiayai suatu bidang yang berbeda dalam proyek tersebut. Dengan demikian, masing-masing bank akan memperoleh keuntungan sesuai dengan bidang yang dibiayai dalm proyek tersebut. Jelasnya hubungan antara peserta sindikasi ini hanya sebatas hubungan koordinatif.

c. Sub syndication, yakni bentuk sindikasi yang antara suatu bank dengan salah satu bank peserta sindikasi lain dan kerjasama bisnis yang dilakukan keduanya tidak berhubungan secara langsung dengan peserta sindikasi lainnya.

5. Pembiayaan Berdasarkan Take Over

Salah satu bentuk jasa pelayanan keuangan bank syariah adalah membantu masyarakat untuk mengalihkan transaksi non-syariah yang masih berajalan menjadi transaksi yang sesuai dengan syariah. Dalam hal ini, atas permintaan nasabah bank mengambil alih hutang nasabah di bank konvensional dengan cara memberikan jasa hiwatah atau dapat juga menggunakan qard\} disesuaikan dengan ada atau tidaknya unsur bunga dalam hutang nasabah kepada bank konvensional. Setelah nasabah melunasi kewajibannya kepada bank konvensional, transaksi yang terjadi adalah transaksi antara nasabah dengan bank syariah. Dengan demikian, yang dimaksud dengan pembiayaan take over adalah pembiayaan yang timbul sebagai akibat dari take over terhadap transaksi non-syariah yang telah berjalan yang dilakukan oleh bank syariah atas permintaan nasabah.

6. Pembiayaan Letter of Credit (L/C)

Pembiayaan letter of credit adalah bentuk pembiayaan yang diberikan dalam rangka memfasilitasi transaksi impor atau ekspor nasabah. Pada umunya, pembiayaan L/C dapat menggunakan beberapa akad. Untuk pembiayaan L/C Impor berdasarkan fatwa Dewan Syariah Nasional Nomor 34/DSN-MUI/IX/2002, akad yang dapat digunakan untuk pembiayaan L/C Impor adalah wakatah bi al-ujrah, wakatah bi al-ujrah dengan qard\} murabahłh, salam atau istisłeas dan murabahłh, wakatah bi al-ujrah dan mudłrabah, mushaðakah, dan wakatah bi al-ujrah dan hiwateh. Adapun untuk pembiayaan L/C Ekspor, berdasarkan fatwa Dewan Syariah Nasional Nomor 35/DSN-MUI/IX/2002, akad yang dapat digunakan untuk pembiayaan L/C Ekspor adalah wakateh bi al-ujrah,

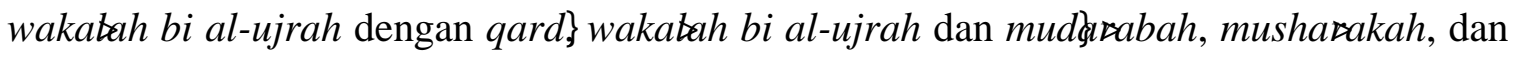
bay' dan wakatah. ${ }^{8}$

\section{Penentuan Kebijakan Pembiayaan di Bank Syariah}

\footnotetext{
${ }^{8}$ Adiwarman A. Karim, Bank Islam, 236-237.
} 
Penentuan sektor-sektor pembiayaan bank syariah ditetapkan bersama oleh dewan komisaris, direksi (termasuk Komite Kebijakan Pembiayaan) serta dewan pengawas syariah, baik mengenai jenis maupun besarnya (nilai rupiahnya) sehingga pilihan yang ditentukan diharapkan memenuhi aspek shar' $i$ di samping aspek ekonomisnya.

Proses pemberian pembiayaan meliputi: ${ }^{9}$

1. Surat permohonan pembiayaan

Dalam surat permohonan, berisikan jenis pembiayaan yang diminta nasabah, untuk berapa lama, berapa limit yang diminta, serta sumber pelunasan pembiayaan berasal dari mana. Di samping itu, surat di atas dilampiri dengan dokumen pendukung, antara lain identitas pemohon, legalitas (akta pendirian atau perubahan, surat keputusan menteri, perizinan-perizinan), bukti kepemilikan agunan (jika diperlukan).

2. Proses evaluasi

Dalam penilaian suatu permohonan, bank syariah tetap berpegang pada prinsip kehati-hatian serta aspek lainnya, sehingga diharapkan dapat diperoleh hasil analisis yang cermat dan akurat.

Langkah pengamanan yang dilakukan bank syariah untuk mengendalikan terjadinya pembiayaan bermasalah dapat dilakukan sebagai berikut: ${ }^{10}$

a. Sebelum realisasi pembiayaan

Dalam tahapan ini, bank melakukan penutupan asuransi dan/atau pengikatan agunan (jika diperlukan). Setelah ini selesai, baru pembiayaan dapat dicairkan.

b. Setelah realisasi pembiayaan

Dalam tahap awal pencairan, dana diarahkan pada pembiayaan sebagaimana diajukan dalam permohonan atau persetujuan bank, dan jangan sampai "bocor", dalam arti lari ke hal-hal di luar kesepakatan. Selanjutnya, bank melakukan pembinaan dan kontrol atas aktifitas bisnis nasabah.

\section{Prinsip-Prinsip Pemberian Pembiayaan}

Dalam melakukan penilaian permohonan pembiayaan bank syariah, bagian marketing harus memperhatikan beberapa prinsip utama yang berkaitan dengan kondisi secara keseluruhan calon nasabah. Di dunia perbankan syariah, prinsip penilaian dikenal dengan $5 \mathrm{C}$ $+1 \mathrm{~S}$, yaitu: ${ }^{11}$

1. Character

Yaitu penilaian terhadap karakter atau kepribadian calon penerima pembiayaan dengan tujuan untuk memperkirakan kemungkinan bahwa penerima pembiayaan dapat memenuhi kewajibannya.

2. Capacity

Yaitu penilaian secara subyektif tentang kemampuan penerima pembiayaan untuk melakukan pembayaran. Kemampuan diukur dengan catatan prestasi penerima

\footnotetext{
${ }^{9}$ Muhammad Syafi'i Antonio, Bank Syariah, 168.

${ }^{10}$ Adiwarman A. Karim, Bank Islam, 244.

${ }^{11}$ Muhammad, Manajemen Dana, 198.
} 
pembiayaan di masa lalu yang didukung dengan pengamatan di lapangan atas sarana usahanya, seperti toko, karyawan, alat-alat, pabrik serta metode kegiatan.

3. Capital

Yaitu penilaian terhadap kemampuan modal yang dimiliki oleh calon penerima pembiayaan yang diukur dengan posisi perusahaan secara keseluruhan yang ditujukan oleh rasio finansial dan penekanan pada komposisi modalnya.

4. Collateral

Yaitu jaminan yang dimiliki calon penerima pembiayaan. Penilaian ini bertujuan untuk lebih meyakinkan bahwa jika suatu resiko kegagalan pembayaran tercapai terjadi, maka jaminan dapat dipakai sebagai pengganti dari kewajiban.

\section{Condition}

Bank syariah harus melihat kondisi ekonomi yang terjadi di masyarakat secara spesifik melihat adanya keterkaitan dengan jenis usaha yang dilakukan oleh calon penerima pembiayaan. Hal tersebut karena kondisi eksternal berperan besar dalam proses berjalannya usaha calon penerima pembiayaan.

6. Syariah

Penilaian ini dilakukan untuk menegaskan bahwa usaha yang akan dibiayai benarbenar usaha yang tidak melanggar syariah sesuai dengan fatwa DSN. Pengelola tidak boleh menyalahi hukum Islam dalam tindakannya yang berhubungan dengan aktifitas ekonomi.

Memang secara teoritis bahwa yang terpenting pertama adalah karakter dari nasabah calon penerima pembiayaan (nasabah debitur), karena jika karakternya baik, sekalipun kondisinya buruk, nasabah debitur akan tetap berusaha serius dan dengan jujur mengembalikan dana pembiayaan yang telah disepakati dalam perjanjian. Namun tidak dapat dipungkiri bahwa pada kenyataannya jaminan sangat menentukan tingkat keamanan pembiayaan yang disalurkan oleh bank. Di samping itu, keberadaan agunan menjadi sangat penting, dan hal ini berhubungan dengan filosofi dasar dari dana bank, yaitu bahwa dana bank adalah dana nasabah, dana masyarakat, yang oleh karenanya harus dilindungi dan digunakan dengan sangat hati-hati.

\section{Batas-Batas Pemberian Pembiayaan}

Dalam menyalurkan pembiayaan, bank syariah akan memperhatikan batas-batas pemberian pembiayaan. Hal penting yang perlu diperhatikan adalah ketentuan financing deposit ratio yang telah ditetapkan oleh Bank Indonesia. Penentuan batas penyaluran pembiayaan suatu bank syariah sebagaimana yang diatur dalam Undang-Undang Nomor 21 tahun 2008 tentang Perbankan Syariah adalah sebagai berikut:

1. Untuk peminjam dari pihak tidak terkait, batas maksimum pemberiaan pembiayaanya adalah $30 \%$ dari modal bank syariah sesuai dengan ketentuan yang ditetapkan oleh bank Indonesia.

2. Untuk pihak terkait, dalam hal ini yang dimaksudkan adalah pemegang saham yang memiliki $10 \%$ atau lebih dari modal disetor bank syariah, anggota dewan komisaris, anggota direksi, keluarga dari persero perorangan, komisaris, dan direksi, pejabat bank lainnya, serta perusahaan yang di dalamnya terdapat kepentingan dari pihak yang di atas, 
batas maksimum pemberian pembiayaannya $20 \%$ dari modal bank syariah sesuai dengan ketentuan yang ditetapkan oleh Bank Indonesia. ${ }^{12}$

Di samping memperhatikan kebijakan otoritas moneter dalam menentukan batas maksimum pemberian pembiayaan (BMPP), bank syariah juga memperhatikan kebijakan internal bank dalam memberikan pembiayaan. Hal ini berkaitan dengan masalah kecepatan pengambilan keputusan. Pada prinsipnya yang memiliki kewenangan memutus suatu permohonan pembiayaan adalah (pejabat) kantor pusat. Namun jika seluruh permohonan diajukan ke kantor pusat, akan terjadi over load pada suatu unit kerja dan kekosongan pada unit kerja lainnya yang pada akhirnya pembiayaan tidak tersedia secara on time. Sehubungan dengan itu, untuk limit/plafon dalam jumlah tertentu, kantor pusat mendelegasikan wewenang memutus kepada (pejabat) kantor wilayah dan kantor cabang serta kantor cabang pembantu.

Hal yang juga diperhatikan bank dalam menentukan batas maksimum pemberian pembiayaan adalah operasional. Dalam tataran operasional, secara umum dalam kondisi normal, besaran/totalitas pembiayaan sangat tergantung pada besaran dana yang tersedia, baik yang berasal dari pemilik berupa modal serta dana dari masyarakat luas (dana pihak ketiga). Jelasnya, semakin besar funding suatu bank, akan meningkat potensi bank yang bersangkutan dalam penyediaan pembiayaan. Dalam kondisi yang situasional, besarnya porsi pembiayaan dipengaruhi oleh alokasi dana untuk itu, yang di antaranya bank juga mempertimbangkan penyaluran ke sektor lain yang lebih menguntungkan dibanding pembiayaan dapat memberikan hasil yang lebih banyak/baik. ${ }^{13}$

\section{Kesimpulan}

Pembiayaan berdasarkan prinsip syariah adalah penyediaan uang atau tagihan yang dipersamakan dengan itu berdasarkan persetujuan atau kesepakatan antara bank dengan pihak lain yang mewajibkan pihak yang dibiayai untuk mengembalikan uang atau tagihan tersebut setelah jangka waktu tertentu dengan imbalan atau bagi hasil. Dalam melakukan pembiayaan maka bank syariah memerlukan analisis pembiayaan agar bank syariah memperoleh keyakinan bahwa pembiayaan yang diberikan dapat dikembalikan oleh nasabahnya. Namun realisasi pembiayaan bukanlah tahap terakhir dari proses pembiayaan. Setelah realisasi pembiayaan, maka pejabat bank syariah perlu melakukan pemantauan dan pengawasan pembiayaan supaya memajukan efisiensi di dalam pengelolaan tata laksana usaha di bidang peminjaman dan sasaran pencapaian yang ditetapkan sehingga tujuan daripada adanya pembiayaan bisa tercapai.

\section{Daftar Rujukan}

Antonio, Muhammad Syafi'i. Bank Syariah dari Teori ke Praktik. Jakarta: Gema Insani, 2001.

Ismaniar, Hetty. Manajemen Unit Kerja. Yogyakarta: Deepublish, 2015.

Karim, Adiwarman A. Bank Islam. Jakarta: PT. Raja Grafindo Persada, 2010.

Muhammad. Manajemen Dana Bank Syariah. Yogyakarta: Ekonisia, 2004.

\footnotetext{
${ }^{12}$ Undang-Undang Republik Indonesia Nomor 21 tahun 2008 tentang Perbankan Syariah.

${ }^{13}$ Veithal Rivai dan Arviyan Arifin, Islamic Banking: Sebuah Teori Konsep dan Aplikasi (Jakarta: PT. Bumi Aksara, 2010), 782.
} 
. Manajemen Pembiayaan Bank Syariah. Yogyakarta: UPP AMP YKPN, t.th.

Rivai, Veithal dan Arviyan Arifin. Islamic Banking: Sebuah Teori Konsep dan Aplikasi. Jakarta: PT Bumi Aksara, 2010.

Sholihin, Ahmad Ifham. Buku Pintar Ekonomi Syari'ah. Jakarta: Gramedia Pustaka Utama, 2010.

Undang-Undang Republik Indonesia Nomor 21 tahun 2008 tentang Perbankan Syariah. 